\section{ECONOMICS}

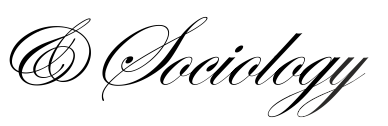

Gallardo-Vázquez, D., \& Lizcano-Álvarez, J. L. (2020). CSR-related competitiveness and legitimacy in MSMEs. Economics and Sociology, 13(1), 52-73. doi:10.14254/2071-789X.2020/13-1/4

\title{
CSR-RELATED COMPETITIVENESS AND LEGITIMACY IN MSMEs
}

\author{
Dolores Gallardo-Vázquez \\ Department of Financial Economy \\ and Accounting, \\ Faculty of Economics and Business \\ Studies, \\ University of Extremadura, \\ Av Elvas s/n 06006 \\ Badajoz, Spain \\ E-mail:dgallard@unex.es
}

José Luis Lizcano-Álvarez

Spanish Association of Accounting and Business Administration,

C/ Rafael Bergamin 16 B, 28043

Madrid, Spain

E-mail:joseluis.lizcano@,aeca.es

Received: October, 2019

1st Revision: December, 2019

Accepted: February, 2020

DOI: $10.14254 / 2071-$

789X.2020/13-1/4

JEL Classification: M14, M19, Q56.
ABSTRACT. Corporate social responsibility (CSR) has emerged as an important strategy in business contexts. This study's main objective was to identify and characterize the basic elements of CSR in micro, small, and medium enterprises (MSMEs) that can contribute to improving these companies' competitiveness and legitimacy. The research was based on the premises defining CSR's scope laid out by the Spanish Association of Accounting and Business Administration and the conceptual framework for corporate responsibility proposed by the European Commission's DirectorateGeneral Enterprise and Industry. A 2004 compilation of good practices in small and medium-sized enterprises in Europe provided the foundation for a systematic analysis isolating elements common to the two cited organizations' frameworks. This is a descriptive study, on a sample of 23 companies belonging to the Autonomous Community of Extremadura, in Spain, involved in the practice of CSR and very sensitized to implement this strategy. Based on this list of features, a theoretical framework of CSR was constructed in order to identify the most significant elements and distinguish those of greatest importance to MSMEs' competitiveness and legitimacy. The originality of this study combined public and private CSR frameworks to categorize the distinctive elements of CSR in MSMEs.

Keywords: corporate social responsibility, micro, small, and medium enterprises, legitimacy, competitiveness.

\section{Introduction}

Currently, business contexts are dominated by globalization and internationalization, and competitiveness has become a compulsory consideration for companies. Thus, firms must identify and work on those aspects that contribute to better market positioning (Marín et al., 2012; Calabrese et al., 2013; Boulouta \& Pitelis, 2014; Delgado Ferraz and Gallardo-Vázquez, 2016; Madorran \& García, 2016; Gallardo-Vázquez et al., 2019a, 2019b; Myšková \& Hájek, 2019). The implementation of corporate social responsibility (CSR) strategies is crucial given the numerous benefits that CSR initiatives offer companies (Pivato et al., 2008; Farooq et al., 2017; Li et al., 2017; Martínez-Conesa et al., 2017; Abdelmotaleb et al., 2018; Hao et al., 2018; Platonova et al., 2018; Myšková \& Hájek, 2019). CSR is not a new or recent strategic tool since 
research referring to the most prominent assertions on this topic goes back more than a decade (Hoffman, 2007; Glavas \& Aguinis, 2012; Gallardo-Vázquez et al., 2013; Gallardo-Vázquez \& Sánchez-Hernández, 2014a, 2014b; Moneva-Abadía et al., 2018; Valdez-Juárez et al., 2018).

For example, the Green Paper: Promoting a European Framework for Corporate Social Responsibility (European Commission [EC], 2001) highlights that CSR is companies' voluntary integration of activities concerning not only economic but also social and environmental responsibility. Subsequently, the Spanish Association of Accounting and Business Administration (AECA) issued Document No. 1 of the CSR Commission, Conceptual Framework for Corporate Social Responsibility (AECA, 2004, p. 21), which identifies CSR as the "voluntary commitment of companies to the development of society and the preservation of the environment through their social composition and responsible behavior toward the people and social groups with whom they interact."

The EC's Directorate General Enterprise and Industry (EC, 2004), in turn, produced the report, Corporate Responsibility: Compilation of Cases of Good Practice Among Small and Medium-Sized Enterprises in Europe. This defines a conceptual framework that includes the components of responsible entrepreneurship in economic, social, and environmental dimensions, which are the basis for the notion of "sustainable development." Subsequently, the Renewed Strategy (EC, 2011) pointed out that companies are responsible for their impacts on society. The cited document expressly refers to the need for collaboration with stakeholders to "integrate social, environmental and ethical concerns; respect for human rights; and consumer concerns in their business operations and basic strategies" (EC, 2011, p. 7).

One important aspect of CSR that makes it so universally applicable is its large scope. At first, mostly large companies appeared to implement socially responsible initiatives (Perrini et al., 2007; Bradford \& Fraser, 2008; Fassin, 2008; Fassin et al., 2011; Valenzuela et al., 2015; Gherghina \& Vintilă, 2016; Grabara et al., 2016; Halim et al., 2017; Dilling \& Caykoylu, 2019), but later small and medium-sized companies also applied this strategy (Gallo, 2004; Murillo \& Lozano, 2006; Preuss \& Perschke, 2010; González-Loureiro \& Pita-Castelo, 2012; GallardoVázquez et al., 2013; Gallardo-Vázquez \& Sánchez-Hernández, 2012, 2014a, 2014b; Raza \& Majid, 2016; Choongo, 2017; Jansson et al., 2017; Lee et al., 2017; Choi et al., 2018; GallardoVázquez et al., 2019a). Thus, AECA (2004, p. 27) affirms: CSR can be applied by all types of companies, regardless of their characteristics. The social forms adopted, listing or not in a stock market, public or private nature, size, sector of activity or scope of the organization does not prevent the implementation of CSR. This means CSR is universally applicable in terms of firms' size and nature and the regional context in which they operate (Castilla-Polo et al., 2018).

The application of CSR implies incorporating this strategy into organizations' direction and management, with implications for all functional areas and other related facets, such as corporate governance, strategic direction, management and control, elaboration and validation of corporate information, investment, certification of administrative and production processes, and communication. These implications translate into what can be termed the basic elements of CSR (AECA, 2004).

The present study's main objective was to identify and characterize the essential CSR features that are distinctive of micro, small, and medium enterprises (MSMEs). These elements do not necessarily coincide with the basic CSR features of large companies, but these features contribute to improved competitiveness while, at the same time, functioning as a source of legitimacy for companies. Therefore, this research was based on the premises established by the AECA (2004) and EC (2004), which were used to conduct a systematic analysis that identified a selection of elements common to both theoretical frameworks. The study is a first step when evaluating the performance of companies, so it is considered preliminary to the idea 
presented by Myšková and Hájek (2019) who also try to evaluate the indicators so that activities can be analyzed from a perspective financial.

This work has focused on 23 companies qualified as socially responsible in Extremadura, which, today, are few in relation to the size of the MSME population in this region. But our intention is to discover a first framework that serves as a reference for later work, evaluating companies from different contexts and making comparative studies after this first step, following the idea from Grabara et al. (2016). Related to the results obtained, we observe that numerous CSR elements are included in the category of distinctive, for example for employees, owner-shareholder, customer, supplier and competitor, local community and corporate information. In relation to competitiveness, more than half of the elements are considered distinctive, and regards to legitimacy we have to point out that very few elements considered are classified as distinctive, being necessary to reinforce these aspects of CSR. As recommendations for the improvement of the results obtained, it is suggested to work more proactively with companies, in such a way that they undertake more and more CSR activities, which would entail a broader qualification for the proposed elements. At the same time, it is recommended to continue working on expanding the study sample, since this can always lead to better results.

The opportunity of this study is justified given the absence of a specific CSR framework. The study presents several contributions: i) first, it contributes to literature in CSR, expanding the existing one and complementing the previous contributions of numerous and rigorous authors; ii) secondly, it defines a framework for CSR, original in the literature, and cannot be compared to previous studies; iii) finally, it provides a very valid diagnostic tool for companies to value themselves and define their level of reach along the path of CSR.

This paper is structured as follows. The introduction defines the research problem and objective. The second section presents the theoretical framework, including distinctive CSR elements in MSMEs and legitimacy theory. The next section describes the descriptive study, while the final section provides the conclusions, theoretical and practical contributions, limitations, and suggestions for future research.

\section{Literature review}

This study focused on MSMEs for a variety of reasons, including that they constitute a part of business ecosystems capable of strongly influencing the economy (EC, 2003; Kobe, 2007; Business, Innovations and Skills, 2008; Machová et al., 2016; Gallardo-Vázquez et al., 2019a; Appiah et al., 2019). MSMEs account for more than 99\% of the Spanish corporate business fabric, so these firms are associated with a great number of economic activities, the capacity to generate employment (i.e., $80 \%$ of the national total), and dynamic competition among these companies. Overall, MSMEs contribute nearly $70 \%$ of Spain's economic value added. This large number of MSMEs underlines the importance of their increasing application of CSR principles and development and implementation of socially responsible initiatives. Common business practices indicate that MSMEs naturally invest in many socially responsible projects, although the way these firms approach CSR is substantially different from other organizations such as large companies or public administrations.

Those works that delve into small and medium-sized companies are noteworthy, analyzing the relevant role that this business fabric plays in regions and countries (GallardoVázquez et al., 2013; Gallardo-Vázquez et al., 2014a, 2014b; Herrera -Madueño et al., 2016a, 2016b; Machová et al., 2016; León et al., 2017; Moneva-Abadía et al., 2018; Valdez-Juárez et al., 2018; Appiah et al., 2019). In small and medium-sized enterprises-especially microenterprises - owners who are also managers focus primarily on solving day-to-day 
problems, which determine the extent to which socially responsible initiatives can be developed. Depending on the owners' personality and values (Jenkins, 2006; Murillo \& Lozano, 2006), these entrepreneurs show a stronger or weaker inclination toward engaging in social or solidarity projects. These initiatives can go beyond a mere compliance with the law including, for example, continuous training (Delgado Ferraz \& Gallardo-Vázquez, 2016; Machová et al., 2016; Edinger-Schons et al., 2019), job security, and involvement in community projects (Kaufmann \& Simons-Kaufmann, 2016; Chang et al., 2018). Other projects involve promoting cultural initiatives, controlling environmental impacts, integrating minorities and people with disabilities, supporting fair trade (Moore et al., 2009), or addressing an extremely diverse range of other issues (International Organization for Standardization, 2010; Stubblefield Loucks et al., 2010; Pastrana \& Sriramesh, 2014). In the context of Romania, CSR has grown in interest in recent years, noting that the companies involved in these projects invest a considerable amount (Grabara et al., 2016). At the same time, there is a relationship between capital investment and decisions taken, which is crucial when carrying out CSR initiatives (Kengatharan \& Clamenthu, 2017).

MSMEs are organizations in which interpersonal relationships and informal communication are extremely important (Russo and Tencati, 2009; Stubblefield Loucks et al., 2010; Machová et al., 2016; Westman et al., 2019) so that, when these are well managed, they can be essential elements encouraging stability and organizational security. The cultivation of proximity in relationships with workers and in the overall social environment stabilizes employees' expectations of social relationships and generates a more or less generalized climate of trust that radiates to all stakeholders (i.e., suppliers, clients, communities, and even competitors) (Vance, 2006; Ongori, 2007; Rettab et al., 2009; Akintayo, 2010; Ali et al., 2010; Looser and Wehrmeyer, 2015). In addition, MSMEs' social and relational capital generates a good reputation and image of professionalism, as well as functioning as a factor in a level of confidence that, in turn, enhances worker retention, improved relationships with financial institutions, and sustainability over time.

Besides the aforementioned specificities, various external and internal agents enhance CSR in MSMEs. Among the former are consumers (Jenkins, 2006; Niehm et al., 2007; Perrini et al., 2007; Stubblefield Loucks et al., 2010; Youssef et al., 2018), large companies, public administrations, and the media. The latter agents include the entrepreneurs' values and search for the best possible results in terms of workplace climate, productivity, innovation, and management (Adams et al., 2016; Machová et al., 2016; Zhang et al., 2019). Consumers expect companies to offer minimum levels of quality and to commit to ethical conduct. The certification process is helping to introduce good CSR practices, which often are required by the large companies that contract MSMEs as suppliers. Public administrations have also begun to promote CSR in MSMEs through calls for tenders for service contracts, which include specific CSR requirements (Aragón-Correa et al., 2008; Stubblefield Loucks et al., 2010). As a result of optimal CSR management, SMEs show competitive success, as well as growth and development (Kozlowski \& Matejun, 2016).

Once the study framework has been developed, companies can assess the degree of implementation of their socially responsible actions, reaching a degree of measurement, an aspect on which no agreement has been found in the literature. So far, numerous scales have been addressed (DÁprile \& Taló, 2014; Gallardo-Vázquez et al., 2013; Maignan \& Ferrell, 2000; Mory et al., 2016; Quazi \& O'Brien, 2000; Taghian et al., 2015; Turker, 2009; Yeh, 2015), although the previous step that we take in this work is convenient.

The above review highlights the distinctive features of CSR in MSMEs and some of the driving factors. The following subsections define the framework of differentiating elements on 
which the present study was based and which later served as a starting point for an examination of these companies' socially responsible practices.

\subsection{Distinctive CSR Elements in MSMEs}

To identify the basic features of CSR in the context of MSMEs, two sources were used as a theoretical foundation. The first was the CSR Conceptual Framework (AECA, 2004). The second was the conceptual framework included in Corporate Responsibility: Compilation of Cases of Good Practice Among Small and Medium-Sized Enterprises in Europe, published by the EC's (2004) Directorate General Enterprise and Industry.

Based on these two studies, a systematic analysis was carried out to extract CSR elements common to both organizations' theoretical framework. The first study presents the basic features of CSR that take into account the internal or external nature of interest groups. Companies' economic, social, and environmental initiatives can be categorized based on this approach. The second conceptual framework delineates the pillars of sustainable development, which the present research understood to be achievable through applications of CSR in economic, social, and environmental spheres.

After clarifying the premises established by both frameworks, this study sought to create a set of indicators that are common to both approaches and that can express both the definition, scope, and basic elements of CSR for an extremely wide range of businesses. The research also focused on CSR features of great value to the economy, as is the case of MSMEs' initiatives. Figure 1 shows the elements common to both frameworks, which were used to develop a questionnaire administered to a sample of experts made up of company representatives (i.e., one from each company selected).

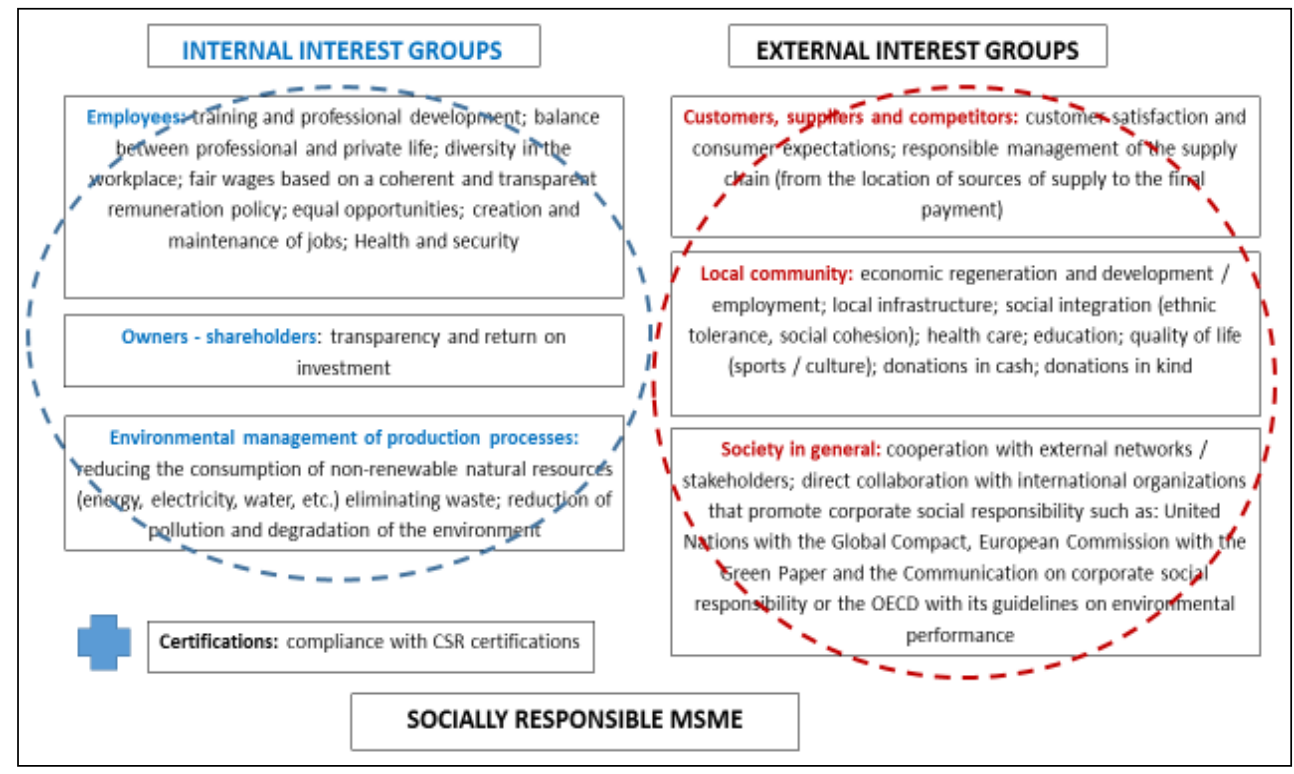

Figure 1. Elements defining socially responsible MSMEs Source: Adapted from AECA (2004) and EC (2004)

As we can see in Figure 1, the common elements have been distributed in two large groups according to the classification of internal and external stakeholders. The aspects to work in each of the groups are identified in the figure. Thus, within the internal interest groups, employees, owners-shareholders stand out, as well as the environmental management of production processes. On the other hand, customers, suppliers, competitors, the local 
community and society in general are observed within the external interest groups. Numerous authors consider that employees are the true internal resources of companies (Gallardo et al., 2016; Farooq et al., 2017; Hao et al., 2018), because they are able to encourage with initiatives and show a strong committment with the organization. External interest groups are equally important, since although they are not part of the structure of the organization, but are linked to it and participate in its activity (El Akremi et al., 2015; Farooq et al., 2014; Gallardo et al., 2016; Stoian \& Gilman, 2017).

Once the elements that define an MSME as socially responsible were clear, this study sought to link the development of CSR initiatives with the legitimacy that these provide MSMEs in their sector or market. The questionnaire thus sought to identify CSR initiatives that are determinants of these companies' legitimacy.

\subsection{CSR as an Element of MSMEs' Legitimacy}

The present research examined how the implementation of CSR initiatives is a determinant of organizational legitimacy. This study applied Suchman's (1995, p. 574) definition of legitimacy as "the generalized perception or assumption that the activities of an entity are desirable, proper, or appropriate within some socially constructed system of norms, values, beliefs, and definitions." This consistency with the social systems in which organizations operate is a key point for firms and, especially, MSMEs need to consider since they must identify the relevant factors to achieve legitimacy. Bitektine (2011) explaines legitimacy as the judgement of an organization that the society develops. Later, Bitektine and Haack (2015) point out that although legitimacy can be considered an organizational asset, a social evaluation from observers is fundamental. Very recently, Derakhshan et al. (2019) state that organizational legitimacy highlights the importance of social acceptance of organizations.

Companies' legitimacy in their immediate context requires the fulfillment of a "social contract" in which they agree to satisfy a series of social demands, thereby receiving general approval of their objectives and additional rewards that guarantee these firms' existence (Deegan, 2002; Deephouse \& Suchman, 2008). From this perspective, organizations can generate substantial support from internal stakeholders when professional development, conciliation, diversity, equality, and a fair, transparent policy of remuneration are promoted. These internal policies are positively related to support from suppliers, customers, and even competitors.

In addition, good supply chain management needs to work for local communities by promoting social integration, quality of life, and the improvement of society as a whole based on collaboration with institutions. This means MSMEs can gain ample access to investment as organizations that have succeeded in legitimizing their operations and making them successful. At the same time, improving internal organizational processes by adopting accepted norms and standards creates organizations in which both internal and external agents want to work and feel motivated to develop business activities and support the initiatives proposed by management. In short, the above undertakings are an expression of good CSR strategies that determine organizations' legitimacy among other entities, especially when these strategies are accepted and desired by these stakeholders. Legitimacy, in turn, contributes to ensuring companies' long-term existence (Williamson \& Lynch-Wood, 2008). On the other hand, organizations can control their legitimacy through changing observers' perceptions (Aerts \& Cormier, 2009).

Concurrently, organizations can take proactive steps to acquire, preserve, or even repair their legitimacy. The adoption of economic, social, or environmental initiatives can be appropriate proactive mechanisms. This indicates that CSR is an attribute capable of 
influencing companies' legitimacy. Lamberti and Lettieri (2011) recommend that managers develop business plans that include activities promoting organizational legitimacy through CSR and corporate strategies because legitimacy is a further source of CSR.

Legitimacy clearly confers acceptability on every organization in the eyes of other entities, as well as desirability over other competitors, which is a source of success in the market. Alcántara et al. (2006) and Tornikoski and Newbert (2007) have confirmed that organizations with greater legitimacy are more likely to succeed. Therefore, discussing CSR implies a focus on legitimacy and competitiveness. In this sense, Gallego-Álvarez et al. (2014) state that companies tend to mimic the CSR activities of local rivals in order to gain legitimacy. Goergen et al. (2016) further consider sustainability and competitiveness to be necessary criteria to attain legitimacy, suggesting that a link exists between these three concepts.

\section{Methodology}

The experts were asked to fill out the aforementioned questionnaire, which was based on the selection of elements common to the two theoretical frameworks functioning as reference points. The items fell into five categories: 1) company characteristics (i.e., sector, respondent's position, and number of employees), 2) internal interest groups (i.e., employees and ownersshareholders), 3) external interest groups (i.e., customers, suppliers, local communities, society in general, and corporate information, verification, and certification, 4) competitiveness, and 5) organizational legitimacy. The questionnaire was composed of 48 items covering basic CSR elements. The experts' responses were given on a Likert scale ranging from 1 ("Totally disagree") to 10 ("Totally agree") to evaluate the items referring to categories 2 and 3 . Categories 4 and 5 were assessed on a scale running from 0 ("Well below average") to 5 ("Average") to 10 ("Well above average"). The questionnaires were sent throughout the month of January 2019. All companies responded adequately within the established deadline. Companies were provided with more information about the two frameworks, in order to provoke their interest and become familiar with them from their review.

Since for some years now, the Autonomous Community of Extremadura has been promoting a lot the implementation of socially responsible actions in companies, holding conferences and seminars to encourage and inform companies, as well as financing research projects that highlight the importance of CSR, we consider it right to address this sample of companies. The companies selected represent the primary, secondary, and tertiary sectors, with the latter contributing the largest number of firms in the sample. These companies were chosen from the population of MSMEs in the Autonomous Community of Extremadura, Spain, that had previously been classified as socially responsible or sensitized to the need to implement CSR strategies more or less continuously. These are thus companies publicly recognized for their good CSR practices, in which the tendency is to include those elements more generally employed by MSMEs, thereby fitting into the framework of distinctive elements created for this research. In total, 23 companies belonging to the primary, secondary, and tertiary sectors were selected for the study. The sample is small because it has focused on a business phenomenon with a track record of a few years, so today there are few companies that meet the criteria to be qualified as socially responsible. However, we consider that for the object of study it is an adequate sample and can provide valuable results and future study in a greater number of companies.

Notably, the Extremadura region enacted Law 15/2010 on Corporate Social Responsibility of the Autonomous Community of Extremadura in 2010, as well as Decree 110/2013 of July 2, which created the Autonomous Council for the Promotion of Social Responsibility in Extremadura and the Office of Corporate Social Responsibility. This 
legislation regulates the procedures companies must follow to qualify for and be listed on the Register of Socially Responsible Companies in Extremadura (i.e., DOE, $n^{\circ} 130$, July 8), which seeks to fill out the framework of regional companies' CSR initiatives. This has thus generated a range of programs that encourage CSR among Extremadura companies, thereby promoting socially responsible initiatives and motivating firms to engage in CSR activities. This official support has given companies significant incentives, but implementation has proven to be a complex task so that, at the time of this study, only 23 companies could be identified as having met the first requirement of being involved in and sensitized to CSR.

A descriptive analysis was conducted of the data collected to classify the basic CSR features in MSMEs according to the elements' importance. This could then be used as a reference point for socially responsible behaviors more characteristic of MSMEs. Concurrently, specific deficiencies and opportunities for improvement could be identified using these basic elements. A limitation of the results discussed below is the small number of companies in the sample, but the results provide a first impression that then needs to be amplified and improved with data from a larger sample. As we have pointed out, our intention is to define a first framework that serves as a reference for later works. If this framework is adequate, other companies could be evaluated, either from Extremadura, from other Autonomous Communities of Spain, and even foreign companies, in order to make a diagnosis of the distinctive elements at a higher level, since it is always possible to carry out comparative studies after this first step.

Nearly all companies that participated in the study belong to the tertiary or service sector (number $=11$ ), with only 1 firm from the primary and secondary sectors, respectively. Within the service sector, the subsector of "other services" had the highest rate of response with $63.6 \%$ of the participating companies, followed by the audiovisual, health, education, and research and development subsectors with $9.1 \%$ each. Most of the questionnaires were filled out by the firms' president or general director $(46.25 \%)$ or other employees $(30.8 \%)$. Completed questionnaires were also obtained from commercial, production, and human resource managers $(7.1 \%)$. In terms of the companies' number of employees, the most questionnaires were received from micro and small enterprises (38.5\% each), while medium-sized companies contributed $23.1 \%$ (see Figure 2).

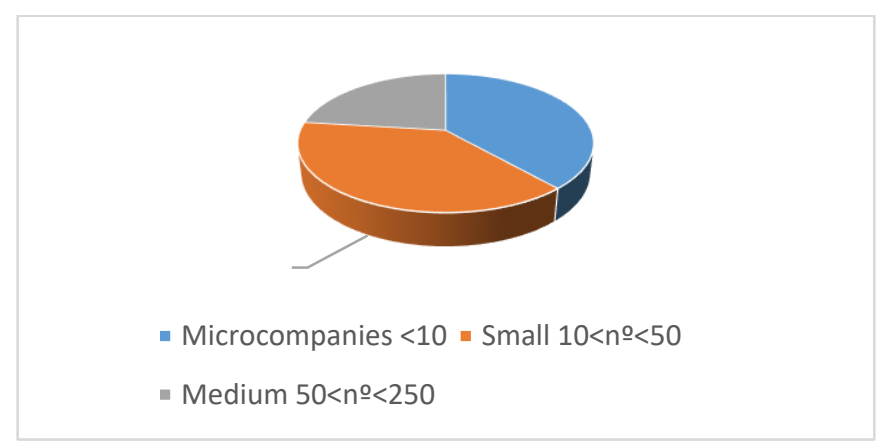

Figure 2. Size of enterprises by number of employees

The level of responses obtained by companies is in line with the proportion of the business fabric in the region, highlighting, first, micro and small enterprises and, secondly, medium sized ones. This is a reality of other Spanish regions as well as at European level.

\subsection{Values Given Basic CSR Elements}

This study sought to categorize the CSR features analyzed by importance and, thus, to develop a list of the basic, distinctive CSR elements of MSMEs. The distinctive CSR features' 
importance was determined by the criterion of at least $54 \%$ of the responses (i.e., 7 of 13) for the relevant items having the values 8,9 , and 10 on the Likert scale used. Thus, the final set of distinctive elements included only those considered extremely important by most companies' participants.

Table 1 shows the values obtained for each CSR element based on the above approach of focusing on the percentage of responses with the values of 8, 9, and 10. According to the established criteria, 27 elements with 8, 9, and 10 values were identified and conceptualized as distinctive CSR features of MSMEs, which can function as a frame of reference for MSMEs. The other 21 elements constitute the elements needing improvement.

Table 1. Basic CSR elements in MSMEs with values given and percentage of responses

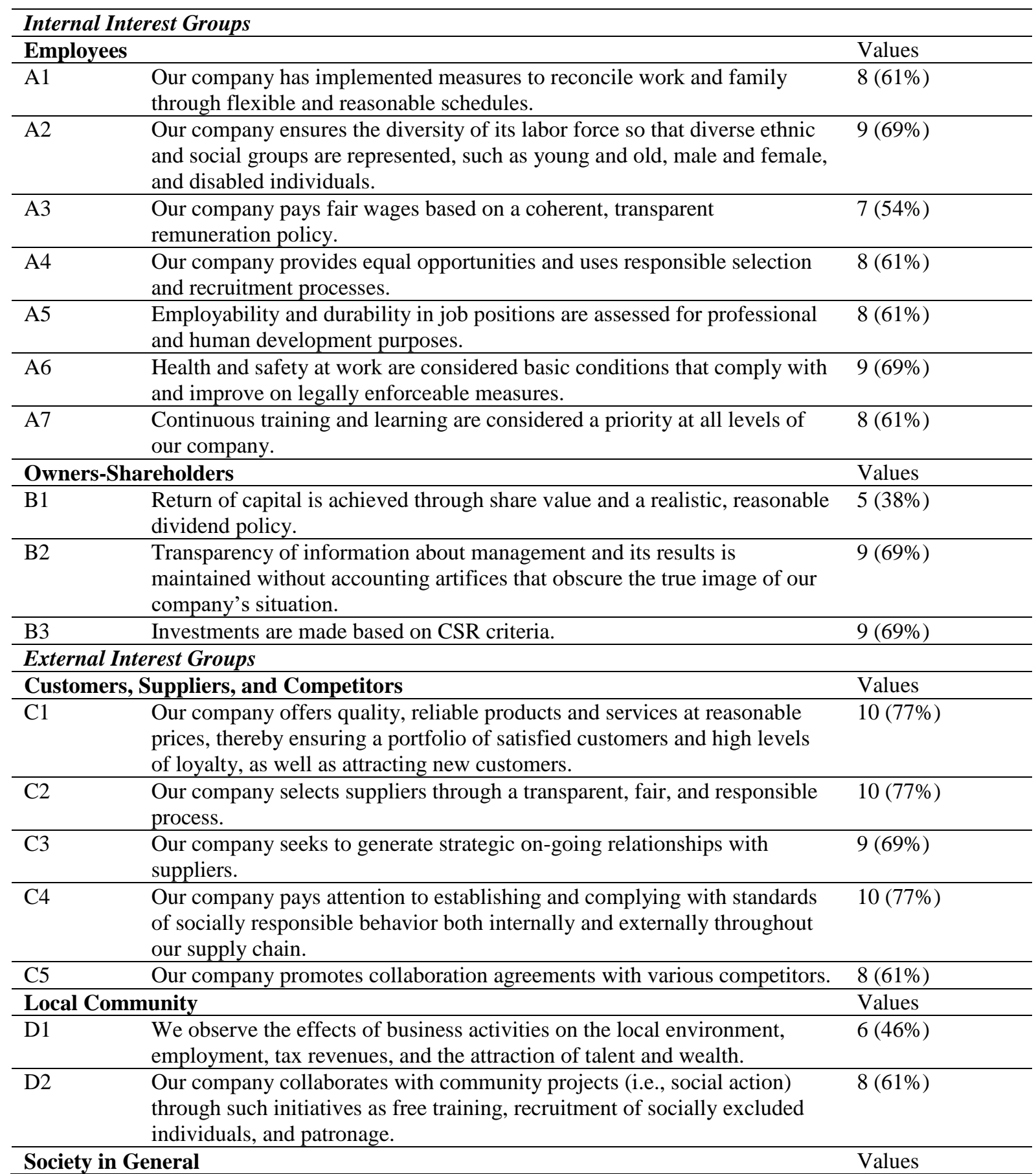




\begin{tabular}{|c|c|c|}
\hline E1 & $\begin{array}{l}\text { Our company directly collaborates with international organizations that } \\
\text { promote CSR such as the United Nations' Global Compact, the European } \\
\text { Commission's Green Paper or the Organization for Economic Cooperation } \\
\text { and Development's (OECD) guidelines on environmental performance. }\end{array}$ & $5(38 \%)$ \\
\hline E2 & $\begin{array}{l}\text { Our company promotes CSR through national or international business } \\
\text { networks that support respect for human rights and the preservation of the } \\
\text { environment. }\end{array}$ & $5(38 \%)$ \\
\hline \multicolumn{2}{|c|}{ Corporate Information, Verification, and Certification } & Values \\
\hline F1 & $\begin{array}{l}\text { Our company undertakes the preparation and periodic publication of CSR } \\
\text { information (i.e., economic, social, environmental, and corporate } \\
\text { governance). }\end{array}$ & $4(30 \%)$ \\
\hline$\overline{\mathrm{F} 2}$ & Our company verifies CSR information through independent third parties. & $6(46 \%)$ \\
\hline F3 & Our company complies with CSR certification guidelines. & $7(54 \%)$ \\
\hline \multicolumn{2}{|c|}{ Competitiveness } & Values \\
\hline G1 & Our excellent human resource management & $6(46 \%)$ \\
\hline G2 & Our staff's level of training & $10(77 \%)$ \\
\hline G3 & Our managers' administrative skills & $7(54 \%)$ \\
\hline G4 & Our marketing capabilities & $6(46 \%)$ \\
\hline G5 & The quality of our products and services & $12(92 \%)$ \\
\hline G6 & Our level of organizational quality and administrative management & $6(46 \%)$ \\
\hline G7 & Our technological resources and information systems & $7(54 \%)$ \\
\hline G8 & The transparency of our financial management & $11(84 \%)$ \\
\hline G9 & Our cohesive values and corporate culture & $8(61 \%)$ \\
\hline G10 & Our market knowledge, know-how, and accumulated experience & $6(46 \%)$ \\
\hline \multicolumn{2}{|c|}{ Organizational Legitimacy } & Values \\
\hline H1 & $\begin{array}{l}\text { Our company has obtained increasing returns since we implemented CSR } \\
\text { strategies. }\end{array}$ & $3(23 \%)$ \\
\hline $\mathrm{H} 2$ & We have observed an increase in productivity. & $3(23 \%)$ \\
\hline $\mathrm{H} 3$ & We can say that our company is successfully competitive. & $6(46 \%)$ \\
\hline $\mathrm{H} 4$ & We have seen an increase in return on investment. & $4(30 \%)$ \\
\hline H5 & $\begin{array}{l}\text { We have noticed a reduction in costs since we implemented CSR } \\
\text { strategies. }\end{array}$ & $3(23 \%)$ \\
\hline H6 & We have improved our relationships with consumers. & $7(54 \%)$ \\
\hline H7 & Our company has been able to attract new investment. & $5(38 \%)$ \\
\hline $\mathrm{H} 8$ & Our company is able to attract new talent. & $4(30 \%)$ \\
\hline H9 & Our company fosters an internal culture of social awareness. & $6(46 \%)$ \\
\hline H10 & $\begin{array}{l}\text { Our staff shows a high degree of involvement and pride in belonging to our } \\
\text { company. }\end{array}$ & $5(38 \%)$ \\
\hline H11 & $\begin{array}{l}\text { Our company's communication and credibility are reinforced by CSR } \\
\text { initiatives. }\end{array}$ & $4(30 \%)$ \\
\hline H12 & Our staff shows a greater commitment to the company. & $7(54 \%)$ \\
\hline H13 & Our reputation has been consolidated by CSR initiatives. & $4(30 \%)$ \\
\hline H14 & We have observed greater brand loyalty. & $8(61 \%)$ \\
\hline $\mathrm{H} 15$ & Our image is very positive. & $8(61 \%)$ \\
\hline H16 & $\begin{array}{l}\text { We have received greater recognition in the sector and in the market in } \\
\text { which we operate. }\end{array}$ & $9(69 \%)$ \\
\hline
\end{tabular}

\subsection{Proposed List of Basic CSR Elements in MSMEs}

The most essential, distinctive CSR features are listed in Table 2 based on the responses of the companies' participants. 
Table 2. Essential, distinctive CSR elements in MSMEs

\begin{tabular}{|c|c|c|}
\hline \multicolumn{3}{|c|}{ Internal Interest Groups } \\
\hline \multicolumn{2}{|c|}{ Employees } & \multirow{2}{*}{$\begin{array}{l}\text { Values } \\
8(61 \%)\end{array}$} \\
\hline A1 & $\begin{array}{l}\text { Our company has implemented measures to reconcile work and family } \\
\text { through flexible, reasonable schedules. }\end{array}$ & \\
\hline A2 & $\begin{array}{l}\text { Our company pays attention to diversity so that our labor force represents } \\
\text { diverse ethnic and social groups, such as young and old, male and female, } \\
\text { and disabled individuals. }\end{array}$ & $9(69 \%)$ \\
\hline A3 & $\begin{array}{l}\text { Our company pays fair wages based on coherent, transparent remuneration } \\
\text { policies. }\end{array}$ & $7(54 \%)$ \\
\hline A4 & $\begin{array}{l}\text { We offer equal opportunities and conduct responsible selection and } \\
\text { recruitment processes. }\end{array}$ & $8(61 \%)$ \\
\hline A5 & $\begin{array}{l}\text { Employability and durability in job positions are assessed for professional } \\
\text { and human development purposes. }\end{array}$ & $8(61 \%)$ \\
\hline A6 & $\begin{array}{l}\text { Health and safety at work are considered basic conditions complying with } \\
\text { and improving legally enforceable measures. }\end{array}$ & $9(69 \%)$ \\
\hline A7 & $\begin{array}{l}\text { Continuous training and learning are considered essential and a priority at all } \\
\text { levels of our organization. }\end{array}$ & $8(61 \%)$ \\
\hline \multicolumn{2}{|c|}{ Owners-Shareholders } & Values \\
\hline B2 & $\begin{array}{l}\text { Transparency of information about management and results is maintained } \\
\text { without resorting to accounting artifices that obscure the true image of our } \\
\text { company's situation. }\end{array}$ & $9(69 \%)$ \\
\hline B3 & Investments are made based on CSR criteria. & $9(69 \%)$ \\
\hline \multicolumn{3}{|c|}{ External Interest Groups } \\
\hline \multicolumn{2}{|c|}{ Customers, Suppliers, and Competitors } & Values \\
\hline $\mathrm{C} 1$ & $\begin{array}{l}\text { Our company offers quality, reliable products and services at reasonable } \\
\text { prices, thereby ensuring a portfolio of satisfied customers and high levels of } \\
\text { loyalty, as well as attracting new customers. }\end{array}$ & $10(77 \%)$ \\
\hline $\mathrm{C} 2$ & $\begin{array}{l}\text { Our company selects suppliers through a transparent, fair, and responsible } \\
\text { process. }\end{array}$ & $10(77 \%)$ \\
\hline $\mathrm{C} 3$ & $\begin{array}{l}\text { Our company seeks to develop strategic on-going relationships with } \\
\text { suppliers. }\end{array}$ & $9(69 \%)$ \\
\hline $\mathrm{C} 4$ & $\begin{array}{l}\text { Our company pays attention to establishing and complying with standards of } \\
\text { socially responsible behavior both internally and in our supply chain. }\end{array}$ & $10(77 \%)$ \\
\hline C5 & Our company promotes collaboration agreements with various competitors. & $8(61 \%)$ \\
\hline \multicolumn{2}{|c|}{ Local Community } & Values \\
\hline D2 & $\begin{array}{l}\text { Our company collaborates with community projects (i.e., social action) } \\
\text { through such initiatives as free training, the recruitment of socially excluded } \\
\text { individuals, and patronage. }\end{array}$ & $8(61 \%)$ \\
\hline \multicolumn{2}{|c|}{ Corporate Information, Verification, and Certification } & Values \\
\hline F3 & Our company complies with CSR certification guidelines. & $7(54 \%)$ \\
\hline \multicolumn{2}{|c|}{ Competitiveness } & Values \\
\hline G2 & Our staff's level of training & $10(77 \%)$ \\
\hline G3 & Our managers' administrative skills & $7(54 \%)$ \\
\hline G5 & The quality of our products and services & $12(92 \%)$ \\
\hline G7 & Our technological resources and information systems & $7(54 \%)$ \\
\hline G8 & The transparency of our financial management & $11(84 \%)$ \\
\hline G9 & The cohesiveness of our values and corporate culture & $8(61 \%)$ \\
\hline \multicolumn{2}{|c|}{ Organizational Legitimacy } & Values \\
\hline H6 & Our company has improved its relationship with consumers. & $7(54 \%)$ \\
\hline $\mathrm{H} 12$ & Our clients show a greater commitment to the company. & $7(54 \%)$ \\
\hline H14 & We have observed stronger brand loyalty. & $8(61 \%)$ \\
\hline H15 & Our image is very positive. & $8(61 \%)$ \\
\hline H16 & We have received recognition in our sector and market. & $9(69 \%)$ \\
\hline
\end{tabular}




\subsection{Basic CSR Elements Inadequately Developed in MSMEs}

The analysis thus produced a list of distinctive CSR features by order of their importance. Table 3 below shows the basic CSR elements that need to be improved and developed more fully by MSMEs. These features are those that were given values lower than 8. Some interpretations of these results are discussed in the following subsection.

Table 3. Basic CSR elements that can be improved in MSMEs

\begin{tabular}{|c|c|c|}
\hline \multicolumn{3}{|c|}{ Internal Interest Groups } \\
\hline \multicolumn{2}{|c|}{ Owners-Shareholders } & \multirow{2}{*}{$\begin{array}{l}\text { Values } \\
5(38 \%)\end{array}$} \\
\hline B1 & $\begin{array}{l}\text { Return of capital is achieved through share value and a realistic, reasonable } \\
\text { dividend policy. }\end{array}$ & \\
\hline \multicolumn{3}{|c|}{ External Interest Groups } \\
\hline \multicolumn{2}{|c|}{ Local Community } & Values \\
\hline D1 & $\begin{array}{l}\text { We monitor the effects of our business activities on the local environment, } \\
\text { employment, tax revenues, and the attraction of talent and wealth. }\end{array}$ & $6(46 \%)$ \\
\hline \multicolumn{2}{|c|}{ Society in General } & Values \\
\hline E1 & $\begin{array}{l}\text { Our company collaborates directly with international organizations that } \\
\text { promote CSR, such as the United Nations' Global Compact, the European } \\
\text { Commission's Green Paper, or the OECD's guidelines on environmental } \\
\text { performance. }\end{array}$ & $5(38 \%)$ \\
\hline E2 & $\begin{array}{l}\text { Our company promotes CSR through national or international business } \\
\text { networks that support respect for human rights and the preservation of the } \\
\text { environment. }\end{array}$ & $5(38 \%)$ \\
\hline \multicolumn{2}{|c|}{ Corporate Information, Verification, and Certification } & Values \\
\hline F1 & $\begin{array}{l}\text { Our company undertakes the preparation and periodic publication of CSR } \\
\text { information (i.e., economic, social, environmental, and corporate } \\
\text { governance). }\end{array}$ & $4(30 \%)$ \\
\hline $\mathrm{F} 2$ & Our company verifies CSR information through independent third parties. & $6(46 \%)$ \\
\hline \multicolumn{2}{|c|}{ Competitiveness } & Values \\
\hline G1 & Our excellent human resource management & $6(46 \%)$ \\
\hline G4 & Our marketing capabilities & $6(46 \%)$ \\
\hline G6 & Our levels of organizational quality and administrative management & $6(46 \%)$ \\
\hline G10 & Our market knowledge, know-how, and accumulated experience & $6(46 \%)$ \\
\hline \multicolumn{2}{|c|}{ Organizational Legitimacy } & Values \\
\hline H1 & $\begin{array}{l}\text { Our company has obtained increasing returns since implementing CSR } \\
\text { strategies. }\end{array}$ & $3(23 \%)$ \\
\hline $\mathrm{H} 2$ & We have experienced an increase in productivity. & $3(23 \%)$ \\
\hline H3 & We can say that our company is successfully competitive. & $6(46 \%)$ \\
\hline $\mathrm{H} 4$ & We have seen an increase in return on investment. & $4(30 \%)$ \\
\hline H5 & $\begin{array}{l}\text { We have noticed a reduction in costs since the implementation of CSR } \\
\text { strategies. }\end{array}$ & $3(23 \%)$ \\
\hline $\mathrm{H7}$ & Our company has been able to attract new investment. & $5(38 \%)$ \\
\hline H8 & Our company is able to attract new talent. & $4(30 \%)$ \\
\hline H9 & Our company has a culture of social awareness. & $6(46 \%)$ \\
\hline H10 & $\begin{array}{l}\text { Our staff shows a high degree of involvement and pride in belonging to the } \\
\text { company. }\end{array}$ & $5(38 \%)$ \\
\hline H11 & $\begin{array}{l}\text { Our company's communication and credibility have been reinforced by CSR } \\
\text { initiatives. }\end{array}$ & $4(30 \%)$ \\
\hline H13 & Our reputation has been consolidated by CSR initiatives. & $4(30 \%)$ \\
\hline
\end{tabular}




\subsection{Interpretation of results and discussion}

The CSR elements related to employee interest groups (items A1, A2, A3, A4, A5, A6, and A7), and customers, suppliers, and competitors (C1, C2, C3, C4, and C5) are included in the category of important features with values equal to or greater than 7 . These elements have been considered previously by authors such as Brunton et al. (2017), De Roeck et al. (2018), Ferreira and Real de Oliveira (2014), Gallardo-Vázquez et al. (2013, 2016, 2019a), GallardoVázquez and Sánchez-Hernández (2012, 2014a, 2014b), Herrera-Madueño et al. (2016a, 2016b), Lu et al. (2012), Myšková and Hájek (2019), Popovic et al. (2017) and Turker (2009). In contrast, the section on society in general (E1 and E2) does not include any elements that fall into the category of distinctive CSR features. This reflects MSMEs' concerns about managing the most significant stakeholders in order to achieve these firms' essential objectives and ensure their survival. Their relationship with society as a whole is relegated to a secondary level below that of daily needs. This result contrasts with the importance granted by Popovic et al. (2017), based on Simóes et al. (2016), Turker (2009) and Herrera-Madueño et al. (2016b) who consider society as an impact category, highlighting attention to community support and involvement, as well as stakeholder participation.

Regarding the owner-shareholder interest group, two elements (B2 and B3) are part of the category of distinctive features relating to information transparency and socially responsible investments. MSMEs do not habitually consider the issue of remuneration for capital providers and a reasonable dividend policy (B1). With respect to local communities, a distinctive CSR element is collaborations with community projects, as well as hiring individuals at risk of social exclusion (D2), according with Myšková and Hájek (2019), Turker (2009) and Farooq et al. (2017). However, MSMEs do not give importance to the impact of their business activities on the local environment, employment, taxes, and the attraction of talent and wealth (D1), which received a higher value in only $46 \%$ of the responses. This last result is not reasonable with the existing literature, which indicates the importance of talent in organizations and attention to employment (Gallardo-Vázquez et al., 2013, 2016, 2019a; Gallardo-Vázquez \& Sánchez Hernández, 2012, 2014a , 2014b).

The basic elements not included in the features identified as important or distinctive could be a strategic shortcut to a more adequate adoption of socially responsible management. These elements include the compilation and periodic publication of corporate information on CSR (F1), which only received a value above 7 in $30 \%$ of responses, and the verification of CSR information by an independent third party (F2), with $46 \%$ of the responses above 7 . This result highlights the lack of information that companies provide about the CSR they practice, as well as the need for further verification. The neglect of the first feature mentioned above may be related to the minimal implementation of a CSR culture and associated transparency, and the little utility seen in producing an annual report. Consequently, when this is linked to the results mentioned in the previous paragraph, a lack of measurement or reports prevents the creation of a clear awareness of business activities' impacts on such areas as the environment and employment. In corporate information issues, however, the results include a distinctive element related to compliance with CSR certifications (F3), with a response rate of $54 \%$ over the value of 7 .

Overall, the features related to public perceptions of companies' competitive positioning are those that were given the highest values: the quality of products and services (G5) (GallardoVázquez et al., 2013, 2016, 2019a), transparency in financial management (G8), and staff training levels (G2) (Delgado and Gallardo-Vázquez, 2019). These stand out as of above average importance as they were given the highest values in $92 \%, 84 \%$, and $77 \%$ of the responses, respectively. These results indicate that MSMEs perceive maintaining a reputation 
for quality as a key element (Baldarelli and Gigli, 2014; Jo et al., 2015; Valdez-Juárez et al., 2018), as well as sustaining financial transparency in order to maintain optimal relationships with suppliers of financial resources, which is a key aspect related to MSMEs' survival. In the category of items assessing competitiveness, managerial skills (G3), technological resources and information systems (G7), and corporate culture and values (G9) are also part of these companies' distinctive CSR features (Gallardo-Vázquez et al., 2013, 2016, 2019a; HerreraMadueño et al., 2016b). MSMEs still need to work more on quality human resource management (G1), marketing skills (G4), organizational quality (G6), and accumulated knowhow and experience (G10).

In contrast, the legitimacy-related elements were given below-average values. For example, the perception of increasing returns after CSR initiatives (H1) only received $23 \%$ of responses over the value of 7 , while increased productivity $(\mathrm{H} 2)$ got $23 \%$ and reduced costs since CSR implementation (H5) received 23\%. This result is not in line with the importance of the scope of legitimacy in the sector, as some authors point out (Gallardo-Vázquez et al., 2019b; Lamberti and Lettieri, 2011; Tornikoski and Newbert, 2007). Perhaps the complicated economic situation of recent years has affected the results of strategic policies, including those that may have been carried out in the context of CSR. In addition, the perception of CSR initiatives' effectiveness in terms of reputation (H13) was not given high values by many (i.e., $30 \%$ of responses). This result would be interesting to reassess it in the future, contrasting with the importance attached to the reputation in the paper of Gallardo et al. (2019a). The category of legitimacy assessed 16 elements, of which only 5 are among the distinctive CSR elements for MSMEs: recognition in the sector and market (H16), brand loyalty (H14), a positive image (H15), relationships with consumers (H6), and greater commitment to the company (H12). Likewise, this result must be reassessed by contrasting with the results of Gallardo et al. (2019b).

We believe that a good path has been taken in the CSR research and it has been possible to define the importance of a considerable number of elements, capable of forming a work guide. However, there is a need to continue working on certain aspects, whose valuation has not been sufficiently high.

\section{Conclusions}

This study's objective was to identify and characterize the distinctive elements of CSR in MSMEs in order to contribute to improving these companies' competitiveness and providing them with additional sources of organizational legitimacy. Based on an analysis of two previously published conceptual frameworks, the CSR features were identified, of which a set of 27 elements of considerable importance were found to be distinctive features of these companies.

According to the data gathered with the questionnaire developed for this research, MSMEs are guided by a desire to create a favorable perception among all interest groupsexcept for society as a whole. More specifically, in the category of items assessing employee CSR, the 7 elements proposed can be considered distinctive aspects of CSR in MSMEs. The category of items evaluating owner-shareholder CSR includes 3 features, of which 2 are distinctive. In the category addressing customer, supplier, and competitor CSR, all 5 elements are also distinctive. The local community CSR category includes 2 features, of which only one is distinctive. In the category of corporate information, verification, and certification, three elements were considered, but only one proved to be a distinctive CSR feature of MSMEs.

Regarding competitiveness, of the 10 elements considered, 6 are considered distinctive, which indicates that these companies have a positive perception of the CSR-related steps that 
they must take to maintain a good position compared to the competition. Finally, with respect to organizational legitimacy, of the 16 elements considered, only 5 are distinctive, so MSMEs need to work on strengthening the remaining CSR features. This lack of interest in legitimacy is perhaps determined by MSMEs' focus on addressing day-to-day issues, whereby these firms neglect other CSR initiatives that go beyond what these companies' business operations demand in the short term.

As in all research, some quite concise and clear limitations can be identified, which suggest future lines of investigation. The first is the sample size since only companies qualified as socially responsible could be included, which greatly reduced the number of MSMEs surveyed. These types of companies have not been defined clearly in the literature. However, the present study delineated the sample based on firms' voluntary implementation of socially responsible initiatives that demonstrate a clear sensitivity to CSR and clear intentions to improve in terms of social, economic, and environmental CSR. This approach, nonetheless, accentuated the difficulties generated by the slow process through which these companies can only gradually identify themselves as making progress towards-and being known asdeveloping CSR initiatives.

Further research is planned that will expand the sample by incorporating other companies into the initial study population as their CSR initiatives become public knowledge. The current descriptive study was carried out based on a decision to determine which, if any, CSR elements are distinctive features of MSMEs. The results were also conditioned by the sample size. Once the database becomes broader, an appropriate statistical program can be applied that can facilitate a broader descriptive study, as well as causal, study in order to analyze more exhaustively the relationships between different CSR elements in MSMEs.

\section{Acknowledgement}

The authors would like to express their gratitude for the European Regional Development Fund and the Junta of Extremadura's financial support and, more specifically, the funds provided by the Business Research (INVE) Research Group (SEJ022 code) and by the VI Action Plan 2018-2020 (GR18058). At the same time, this study would not be possible without the generous collaboration of the Spanish Association of Accounting and Business Administration.

\section{References}

Abdelmotaleb, M., Eldin Mohamed Metwally, A.B., Saha, S.K. (2018). Exploring the impact of being perceived as a socially responsible organization on employee creativity. Management Decision, 56(11), 2325-2340. https://doi.org/10.1108/MD06-2017-0552

Adams, R., Jeanrenaud, S., Bessant, J., Denyer, D., Overy, P. (2016). Sustainability-oriented innovation: a systematic review. International Journal of Management Reviews, 18(2), 180-205.

Aerts, W., Cormier, D. (2009). Media legitimacy and corporate environmental communication. Accounting, Organization and Society, 34(1), 1-27.

Akintayo, D. (2010). Work-family role conflict and organizational commitment among industrial workers in Nigeria. International Journal of Psychology Counseling, 2(1), 1-8.

Alcántara, L., Mitauhashi, H., \& Hoshino, Y. (2006). Legitimacy in international joint ventures: it is still needed. Journal of International Management, 12(4), 389-407. doi:10.1016/j.intman.2006.08.002 
Ali, I., Rehman, K. U., Ali, S. I., Yousaf, J., \& Zia, M. (2010). Corporate social responsibility influences, employee commitment and organizational performance. African Journal of Business Management, 4(12), 2796-2801.

Appiah, M. K., Possumah, B. T., Ahmat, N., \& Sanusi, N. A. (2019). Small and medium enterprise's internal resources and investment decisions in Ghana: The resource-based approach. Economics and Sociology, 12(3), 37-53. doi:10.14254/2071-789X.2019/12$3 / 3$

Aragón-Correa, J. A., Hurtado-Torres, N., Sharma, S., \& García-Morales, V. J. (2008). Environmental strategy and performance in small firms: a resource-based perspective. Journal of Environmental Management, 86(1), 88-103. doi:10.1016/j.jenvman.2006.11.022

Asociación Española de Contabilidad y Administración de Empresas. (2004). Marco conceptual de la responsabilidad social corporativa, Documento $\mathrm{n}^{\circ} 1$ de la Comisión de RSC de AECA. Madrid: AECA.

Baldarelli, M.G., \& Gigli, S. (2014). Exploring the drivers of corporate reputation integrated with a corporate responsibility perspective: some reflections in theory and in praxis. Journal of Management and Governance, 18(2), 589-613. Doi: 10.1007/s10997-011-91923

Bitektine, A. (2011). Toward a theory of social judgments of organizations: the case of legitimacy, reputation, and status. Academy of Management Review, 36(1), 151-179.

Bitektine, A., \& Haack, P. (2015). The 'macro' and the 'micro' of legitimacy: toward a multilevel theory of the legitimacy process. Academy of Management Review, 40(1), 49-75.

Boulouta, I., \& Pitelis, C. N. (2014). Who needs CCSR? The impact of corporate social responsibility on national competitiveness. Journal of Business Ethics, 119(3), 349-364. doi: 10.1007/s10551-013-1633-2

Bradford, J., \& Fraser, E. D. G. (2008). Local authorities, climate change and small and medium enterprises: identifying effective policy instruments to reduce energy use and carbon emissions. Corporate Social Responsibility and Environmental Management, 15(3), 156172. doi.org/10.1002/csr.151

Brunton, M., Eweje, G., \& Taskin, N. (2017). Communication corporate social responsibility to internal stakeholders: Walking the walk or just talking the talk? Business Strategy and the Environment, 26, 31-48. Doi: 10.1002/bse.1889

Business, Innovations and Skills. (2008). SME statistics for the UK and regions 2009. London: Department for Business, Innovations \& Skills.

Calabrese, A., Costa, R., Menichini, T., Rosati, F., \& Sanfelice, G. (2013). Turning corporate social responsibility-driven opportunities into competitive advantages: a two-dimensional model. Knowledge and Process Management, 20(1), 50-58. doi:10.1002/kpm.1401

Castilla-Polo, F., Gallardo-Vázquez, D., Sánchez-Hernández, M.I., \& Ruíz-Rodríguez, M.C. (2018). An empirical approach to analyse the reputation-performance linkage in agrifood cooperatives. Journal of Cleaner Production, 195, 163-175. https://doi.org/10.1016/j.jclepro.2018.05.210

Chang, R. D., Zuo, J., Zhao, Z. Y., Soebarto, V., Lu, Y., Zillante, G., \& Gan, X. L. (2018). Sustainability attitude and performance of construction enterprises: a China study. Journal of Cleaner Production, 172, 1440-1451. doi:10.1016/j.jclepro.2017.10.277

Choi, J.H., Kim, S., \& Yang, D.H. (2018). Small and medium enterprises and the relation between social performance and financial performance: Empirical evidence from Korea. Sustainability, 10, 1816, doi:10.3390/su10061816 
Choongo, P. (2017). A longitudinal study of the impact of corporate social responsibility on firm performance in SMEs in Zambia. Sustainability, 9(8), 1-19.

D’Aprile, G., \& Talò, C. (2014). Measuring corporate social responsibility as a psychosocial construct: A new multidimensional scale. Employee Responsibilities and Rights Journal, 26(3), 153-175. https://doi.org/10.1007/s10672-013-9228-8

De Roeck, K., \& Maon, F. (2018). Building the theoretical puzzle of employees' reactions to corporate social responsibility: An integrative conceptual framework and research agenda. Journal of Business Ethics, 149(3), 609-625. doi:10.1007/s10551-016-3081-2

Deegan, C. (2002). The legitimising effect of social and environmental disclosures - a theoretical foundation. Accounting, Auditing and Accountability Journal, 15(3), 282-311. doi:10.1108/09513570210435852

Deephouse, D.L., \& Suchman, M. (2008). Legitimacy in organizational institutionalism. In: Greenwood, R., Oliver, C., Sahlin, K., Suddaby, R. (Eds.), The Sage Handbook of Organizational Institutionalism. Sage, Thousand Oaks, pp. 49-77.

Delgado Ferraz, F. A., \& Gallardo-Vázquez, D. (2016). Measurement tool to assess the relationship between corporate social responsibility, training practices and business performance. Journal of Cleaner Production, 129, 659-672. doi:10.1016/j.jclepro.2016.03.104

Derakhshan, R., Mancini, M., \& Turner, J.R. (2019). Community's evaluation of organizational legitimacy: Formation and reconsideration. International Journal of Project Management, 37, 73-86.

Dilling, P.F.A., \& Caykoylu, S. (2019). Determinants of companies that disclose high-quality integrated reports. Sustainability, 11, 3744, doi:10.3390/su11133744

Edinger-Schons, L.M., Lengler-Graiff, L., Scheidler, S., \& Wieseke, J. (2019). Frontline Employees as Corporate Social Responsibility (CSR) Ambassadors: A Quasi-Field Experiment. Journal of Business Ethics, 157(2), 359-373. https://doi.org/10.1007/s10551-018-3790-9

El Akremi, A., Gond, J.P., Swaen, V., Roeck, K.D., \& Igalens, J. (2015). How do employees perceive corporate responsibility? Development and validation of a multidimensional corporate stakeholder responsibility scale. Journal of Management, 44(2), 619-657. doi:10.1177/0149206315569311

European Commission. (2001). Libro verde. Fomentar un marco Europeo para la responsabilidad social de las empresas. Luxemburg: Oficina de Publicaciones de las Comunidades Europeas. Retrieved from http://eurlex.europa.eu/LexUriServ/site/es/com/2001/com2001_0366es01.pdf

European Commission. (2003). Recomendación de la Comisión de 6 de Mayo de 2003 sobre la definición de microempresas, pequeñas y medianas empresas. Luxemburg: Oficina de Publicaciones de las Comunidades Europeas. Retrieved from http://www.idepa.es/sites/web/idepaweb/Repositorios/galeria_descargas_idepa/definicio npymeUE2003.pdf

European Commission. (2004). Responsabilidad empresarial. Recopilación y casos de buenas prácticas entre pequeñas y medianas empresas de Europa. Luxemburg: Oficina de Publicaciones de las Comunidades Europeas. Retrieved from http://www.xertatu.net/fitxategiak/dokumentuak/up/EC_BuenasPracticasCSR.pdf

European Commission. (2011). Comunicación de la Comisión al Parlamento Europeo, al Consejo, al Comité Económico y Social Europeo y al Comité de las Regiones. Estrategia renovada de la UE para 2011-2014 sobre la responsabilidad social de las empresas. Brussels: European Commission. 
Farooq, O., Payaud, M., Merunka, D., \& Valette-Florence, P. (2014). The impact of corporate social responsibility on organizational commitment: Exploring multiple mediation mechanisms. Journal of Business Ethics, 125(4), 563-580. doi:10.1007/s10551-0131928-3

Farooq, O., Rupp, D. E., \& Farooq, M. (2017). The multiple pathways through which internal and external corporate social responsibility influence organizational identification and multifoci outcomes: The moderating role of cultural and social orientations. Academy of Management Journal, 60(3), 954-985. doi:10.5465/amj.2014.0849

Fassin, Y. (2008). SMEs and the fallacy of formalising CSR. Business Ethics: A European Review, 17(4), 364-379. doi:10.1111/j.1467-8608.2008.00540.x

Fassin, Y., Van Rossem, A., \& Buelens, M. (2011). Small-business owner-managers' perceptions of business ethics and CSR-related concepts. Journal of Business Ethics, 98(3), 425-453. doi:10.1007/s10551-010-0586-y

Ferreira, P., \& Real de Oliveira, E. (2014). Does corporate social responsibility impact on employee engagement? Journal of Workplace Learning, 26(3/4), 232-247. doi:10.1108/JWL-09-2013-0070

Gallardo-Vázquez, D., Moneva-Abadía, J.M., \& Sánchez-Hernández, M.I. (2016). Responsabilidad Social Corporativa Interna. Delimitación Conceptual e Información, AECA, Madrid.

Gallardo-Vázquez, D., \& Sánchez-Hernández, M. I. (2012). Information on corporate social responsibility and sme's environmental responsiveness: a regional study. Economics \& Sociology, 5(2), 103-115.

Gallardo-Vázquez, D., \& Sánchez-Hernandez, M. I. (2014a). Measuring corporate social responsibility for competitive success at a regional level. Journal of Cleaner Production, 72, 14-22. doi:10.1016/j.jclepro.2014.02.051

Gallardo-Vázquez, D., \& Sánchez-Hernández, M. I. (2014b). Structural analysis of the strategic orientation to environmental protection in SMEs. Business Research Quarterly, 17(2), 115-128.

Gallardo-Vázquez, D., Sánchez-Hernández, M. I., \& Corchuelo Martínez-Azúa, M. B. (2013). Validación de un instrumento de medida para la relación entre la orientación a la responsabilidad social corporativa y otras variables estratégicas de la empresa. Spanish Accounting Review, 16(1), 11-23.

Gallardo-Vázquez, D., Valdez-Juárez, L.E., \& Castuera-Díaz, A.M. (2019a). Corporate social responsibility as an antecedent of innovation, reputation, performance, and competitive success: A multiple mediation analysis. Sustainability, 11, 5614. doi:10.3390/su11205614

Gallardo-Vázquez, D., Valdez-Juárez, L.E., \& Lizcano-Álvarez, J.L. (2019b). Corporate social responsibility and intelectual capital: Sources of competitiveness and legitimacy in organizations' management practices. Sustainability, 11, 5843. doi:10.3390/su11205843

Gallego-Álvarez, I., Formigoni, H., \& Pompa Antunes, M.T. (2014). Corporate social responsibility practices at Brazilian firms. RAE Revista de Administração de Empresas, 54(1), 12-27.

Gallo, M. (2004). The family business and its social responsibilities. Family Business Review, 17(2), 135-147. doi:10.1111/j.1741-6248.2004.00009.x

Gherghina, Ş. C., \& Vintilă, G. (2016). Exploring the impact of corporate social responsibility policies on firm value: The case of listed companies in Romania. Economics and Sociology, 9(1), 23-42. doi: 10.14254/2071- 789X.2016/9-1/2 
Glavas, A., \& Aguinis, H. (2012). What we know and don't know about corporate social responsibility: A review and research agenda. Journal of Management, 38(4), 932-968. https://doi.org/10.1177\%2F0149206311436079

Goergen, M., Chahine, S., Wood, G., \& Brewster, C. (2016). Public listing, context and CSR: The effects of legal origin. Journal of Comparative International Management, 19(1), 47-73.

González-Loureiro, M., \& Pita-Castelo, J. (2012). A model for assessing the contribution of innovative SMEs to economic growth: The intangible approach. Economics Letters, 116(3), 312-315.

Grabara, J., Dura, C., \& Drigă, I. (2016). Corporate social responsibility awareness in romania and poland: A comparative analysis. Economics and Sociology, 9(4), 344-359. doi:10.14254/2071-789X.2016/9-4/22

Halim, E. H., Mustika, G., Sari, R. N., Anugerah, R., \& Mohd-Sanusi, Z. (2017). Corporate governance practices and financial performance: The mediating effect of risk management committee at manufacturing firms. Journal of International Studies, 10(4), 272-289.

Hao, Y., Farooq, Q., \& Zhang, Y. (2018). Unattended social wants and corporate social responsibility of leading firms: Relationship of intrinsic motivation of volunteering in proposed welfare programs and employee attributes. Corporate Social Responsibility and Environmental Management, 25(6), 1029-1038.

Herrera-Madueño, J., Larrán-Jorge, M., Lechuga-Sancho, M.P., \& Martínez-Martínez, D. (2016a). Responsabilidad Social en las PYMEs: Análisis Exploratorio de Factores $\begin{array}{llll}\text { Explicativos. Revista de } \quad \text { Contabilidad, 19(1), } & \text { 31-44. }\end{array}$ https://doi.org/10.1016/j.rcsar.2014.10.003

Herrera-Madueño, J., Larrán-Jorge, M., Martínez-Conesa, I., \& Martínez-Martínez, D. (2016b). Relationship between corporate social responsibility and competitive performance in Spanish SMEs: Empirical evidence from a stakeholders perspective. BRQ Business Research Quarterly, 19(1), 55-72. https://doi.org/10.1016/j.brq.2015.06.002

Hoffman, R.C. (2007). Corporate social responsibility in the 1920s: An institutional perspective. Journal of Management History, 13(1), 55-73. https://doi.org/10.1108/17511340710715179

International Organization for Standardization (ISO). (2010). ISO 26000-Social Responsibility. Retrieved from http://www.iso.org/iso/home/standards/iso26000.htm

Jansson, J., Nilsson, J., Modig, F., Hed Vall, G. (2017). Commitment to sustainability in small and medium-sized enterprises: the influence of strategic orientations and management values. Business Strategy and the Environment, 26(1), 69-83. doi:10.1002/bse.1901

Jenkins, H. (2006). Small business champions for corporate social responsibility. Journal of Business Ethics, 67(3), 241-256.

Jo, H., Kim, H., \& Park, K. (2015). Corporate environmental responsibility and firm performance in the financial services sector. Journal of Business Ethics, 131(2), 257-84.

Kaufmann, F., \& Simons-Kaufmann, C. (2016). Corporate social responsibility in Mozambique. In S. Vertigans, S. O. Idowu, \& R. Schmidpeter (Eds.), Corporate social responsibility in sub-Saharan Africa: sustainable development in its embryonic form (pp. 31-50). New York: Springer.

Kengatharan, L., \& Clamenthu, D.P. (2017). Use of capital investment appraisal practices and effectiveness of investment decisions: a study on listed manufacturing companies in Sri Lanka. University of Jaffna.

Kobe, K. (2007). The small business share of GDP, update 2002-2010. Retrieved from https://www.sba.gov/content/small-business-gdp-update-2002-2010 
Kozlowski, R., \& Matejun, M. (2016). Characteristic features of project management in small and medium-sized enterprises. Business Administration and Management, 1, XIX, 3348. doi:10.1524/tul/001/2016-1-003

Lamberti, L., \& Lettieri, E. (2011). Gaining legitimacy in converging industries: evidence from the emerging market of functional food. European Management Journal, 29(6), 462-475.

Lee, H. Y., Kwak, D. W., \& Park, J. Y. (2017). Corporate social responsibility in supply chains of small and medium-sized enterprises. Corporate Social Responsibility and Environmental Management, 24(6), 634-647.

León, G., Benavides Gutiérrez, H.L., \& Castán Farrero, J.M. (2017). Evaluation of the perception and application of social responsibility practices in micro, small and medium companies in Barranquilla. An analysis from the theory of Stakeholders. Estudios Gerenciales, 33(144), 261-270. https://doi.org/10.1016/j.estger.2017.08.003

Li, D., Xin, L., Chen, X., \& Ren, S. (2017). Corporate social responsibility, media attention and firm value: empirical research on Chinese manufacturing firms. Quality \& Quantity, 51(4), 1563-1577.

Looser, S., \& Wehrmeyer, W. (2015). Stakeholder mapping of CSR in Switzerland. Social Responsibility Journal, 11(4), 780-830.

Lu, R.X.A., Lee, P.K.C., \& Cheng, T.C.E. (2012). Socially responsible supplier development: Construct development and measurement validation. International Journal of Production Economics, 140(1), 160-167. doi:10.1016/j.ijpe.2012.01.032

Machová R., Huszárik E.S., \& Šimonová M. (2016). Selected aspects of innovation policy for small and medium sized enterprises. Journal of International Studies, 9(2), 219-232. doi:10.14254/2071-8330.2016/9-2/17

Madorran, C., \& García, T. (2016). Corporate social responsibility and financial performance: The Spanish case. RAE, Revista de Administração de Empresas, 56(1), 20-28.

Marín, L., Rubio, A., \& Maya, S. R. (2012). Competitiveness as a strategic outcome of corporate social responsibility. Corporate Social Responsibility and Environmental Management, 19(6), 364-376. doi:10.1002/csr.1288

Maignan, I., \& Ferrell, O. C. (2000). Measuring corporate citizenship in two countries: The case of the United States and France. Journal of Business Ethics, 23(3), 283-297. https://doi.org/10.1023/A:1006262325211

Martínez-Conesa, I., Soto-Acosta, P., \& Palacios-Manzano, M. (2017). Corporate social responsibility and its effect on innovation and firm performance: An empirical research in SMEs. Journal of Cleaner Production, 142, 2374-2383.

Moneva-Abadía, J. M., Gallardo-Vázquez, D., \& Sánchez-Hernández, M. I. (2018). Corporate Social Responsibility as a Strategic Opportunity for Small Firms during Economic Crises. Journal of Small Business Management, 57(sup2), 172-199. https://doi.org/10.1111/jsbm.12450

Moore, G., Slack, R., \& Gibbon, J. (2009). Criteria for responsible business practice in SMEs: an exploratory case of UK fair trade organisations. Journal of Business Ethics, 89(2), 173 188.

Mory, L., Wirtz, B. W., \& Göttel, V. (2016). Factors of internal corporate social responsibility and the effect on organizational commitment. The International Journal of Human Resource Management, 27(13), 1393-1425. https://doi.org/10.1080/09585192.2015.1072103

Murillo, D., \& Lozano, J. M. (2006). SMEs and CCSR: an approach to CCSR in their own words. Journal of Business Ethics, 67(3), 227-240. 
Myšková, R., \& Hájek, P. (2019). Relationship between corporate social responsibility in corporate annual reports and financial performance of the US companies. Journal of International Studies, 12(1), 269-282.

Niehm, L. S., Swinney, J., \& Miller, N. K. (2007). Community social responsibility and its consequences for family business performance. Journal of Small Business Management, 46(3), 331-350. doi:10.1111/j.1540-627X.2008.00247.x

Ongori, H. (2007). A review of the literature on employee turnover. African Journal of Business Management, 1(3), 49-54. doi: 10.5897/AJBM

Pastrana, N. A., \& Sriramesh, K. (2014). Corporate social responsibility: perceptions and practices among SMEs in Colombia. Public Relations Review, 40(1), 14-24. doi:10.1016/j.pubrev.2013.10.002

Perrini, F., Russo, A., \& Tencati, A. (2007). CSR strategies of SMEs and large firms: evidence from Italy. Journal of Business Ethics, 74(3), 285-300. doi:10.1007/s10551-006-9235-X

Pivato, S., Misani, N., \& Tencati, A. (2008). The impact of corporate social responsibility on consumer trust: the case of organic food. Business Ethics: A European Review, 17, 3 12.

Platonova, E., Asutay, M., Dixon, R., \& Mohammad, S. (2018). The impact of corporate social responsibility disclosure on financial performance: evidence from the GCC Islamic banking sector. Journal of Business Ethics, 151(2), 451-471.

Popovic, T., Kraslawski, A., Barbosa-Póvoa, A., \& Carvalho, A. (2017). Quantitative indicators for social sustainability assessment of society and product responsibility aspects in supply chains. Journal of International Studies, 10(4), 9-36. doi:10.14254/20718330.2017/10-4/1

Preuss, L., \& Perschke, J. (2010). Slipstreaming the larger boats: social responsibility in medium-sized businesses. Journal of Business Ethics, 92, 531-551. doi:10.1007/s10551009-0171-4

Quazi, A.M., \& O'Brien, D. (2000). An empirical test of a cross-national model of Corporate Social Responsibility. Journal of Business Ethics, 25, 33-51. https://doi.org/10.1023/A:1006305111122

Raza, J., \& Majid, A. (2016). Perceptions and practices of corporate social responsibility among SMEs in Pakistan. Quality \& Quantity, 50(6), 2625-2650. doi:10.1007/s11135-015-02812

Rettab, B., Brik, A. B., \& Mellahi, K. A. (2009). Study of management perceptions of the impact of corporate social responsibility on organisational performance in emerging economies: the case of Dubai. Journal of Business Ethics, 89, 371-390. doi:10.1007/s10551-008-0005-9

Russo, A., \& Tencati, A. (2009). Formal vs. informal CSR strategies: evidence from Italian micro, small, medium-sized, and large firms. Journal of Business Ethics, 85, 339-353. doi:10.1007/s10551-008-9736-x

Simões, M., Freitas, C. L., Barbosa-Póvoa, A. P., \& Carvalho, A. (2016). Social Life Cycle Assessment- A framework for mid- and end-point impact categories. Working-paper \#12016, CEG-IST, Instituto Superior Tècnico (Technical University of Lisbon), Portugal.

Stoian, C., \& Gilman, M. (2017). Corporate social responsibility that "Pays": A strategic approach to CSR for SMEs. Journal of Small Business Management, 55(1), 5-31. doi:10.1111/jsbm.12224

Stubblefield Loucks, E., Martens, M. L., \& Cho, C. H. (2010). Engaging small- and mediumsized businesses in sustainability. Sustainability Accounting, Management and Policy Journal, 1(2), 178-200. 
Suchman, M. C. (1995). Managing legitimacy: strategic and institutional approaches. The Academy of Management Review, 20(3), 571-610. doi: 10.2307/258788

Taghian, M., D’Souza, C., \& Polonsky, M. (2015). A stakeholder approach to corporate social responsibility, reputation and business performance. Social Responsibility Journal, 11(2), 340-363. https://doi.org/10.1108/SRJ-06-2012-0068

Tornikoski, E. T., \& Newbert, S. L. (2007). Exploring the determinants of organizational emergence: a legitimacy perspective. Journal of Business Venturing, 22(2), 311-335. doi:10.1016/j.jbusvent.2005.12.003

Turker, D. (2009). Measuring Corporate Social Responsibility: a scale development study. Journal of Business Ethics, 85(4), 411-427. https://doi.org/10.1007/s10551-008-9780-6

Valdez-Juárez, L.E., Gallardo-Vázquez, D., \& Ramos-Escobar, E.A. (2018). CSR and the Supply Chain: Effects on the results of SMEs. Sustainability, 10, 2356. https://doi.org/10.3390/su10072356

Valenzuela Fernánez, L., Jara-Bertin, M., \& Villegas Pineaur, F. (2015). Prácticas de responsabilidad social, reputación corporativa y desempeño financiero. RAE, Revista de Administração de Empresas, 55(3), 329-344.

Vance, R. J. (2006). Employee engagement and commitment. A guide to understanding, measuring and increasing engagement in your organization. Alexandria, VA: SHRM Foundation.

Westman, L., Luederitz, C., Kundurpi, A., Mercado, A.J., Weber, O., \& Burch, S.L. (2019). Conceptualizing businesses as social actors: A framework for understanding sustainability actions in small- and medium-sized enterprises. Business Strategy and the Environment, 28(2), 388-402.

Williamson, D., \& Lynch-Wood, G. (2008). Social and environmental reporting in UK company law and the issue of legitimacy. Corporate Governance: The International Journal of Business in Society, 8(2), 128-140.

Yeh, Y. P. (2015). Corporate social responsibility and service innovation on customer loyalty: An empirical investigation in wealth management services. International Journal of Bank Marketing, 33(6), 823-839. https://doi.org/10.1108/IJBM-09-2014-0130

Youssef, K., Leicht, T., Pellicelli, M., \& Kitchen, P.J. (2018). The importance of corporate social responsibility (CSR) for branding and business success in small and mediumsized enterprises (SME) in a business-to-distributor (B2D) context. Journal of Strategic Marketing, 26(8), 723-739.

Zhang, J.J., Mei, Q., \& Liu, S.X. (2019). Study of the influence of employee safety voice on workplace safety level of small- and medium-sized enterprises. Nankai Business Review International, 10(1), 67-90. 